\title{
E-cadherin regulates proliferation of colorectal cancer stem cells through NANOG
}

\author{
SHINGO TAMURA $^{1}$, TAICHI ISOBE ${ }^{1}$, HIROSHI ARIYAMA ${ }^{1}$, MICHITAKA NAKANO ${ }^{1}$, YOSHIKANE KIKUSHIGE ${ }^{1}$, \\ SHIGEO TAKAISHI ${ }^{1}$, HITOSHI KUSABA ${ }^{3}$, KATSUTO TAKENAKA ${ }^{1}$, TAKASHI UEKI ${ }^{2}$, \\ MASAFUMI NAKAMURA ${ }^{2}$, KOICHI AKASHI ${ }^{1}$ and EISHI BABA ${ }^{3}$ \\ Departments of ${ }^{1}$ Medicine and Biosystemic Science and ${ }^{2}$ Surgery and Oncology, Kyushu University; \\ ${ }^{3}$ Department of Comprehensive Clinical Oncology, Faculty of Medical Sciences, Kyushu University, Fukuoka 812-8582, Japan
}

Received December 16, 2017; Accepted May 17, 2018

DOI: $10.3892 / o r .2018 .6464$

\begin{abstract}
Cancer stem cells (CSCs) possess a self-renewal ability and display tumorigenic potential in immunodeficient mice. Colorectal CSCs are thought to be a uniform population and no functionally distinct subpopulations have been identified. Because E-cadherin is an essential molecule for self-renewal of embryonic stem cells, we examined E-cadherin expression, which may play a role in maintaining the properties of CSCs, in EpCAM ${ }^{\text {high }} / \mathrm{CD} 44^{+}$colorectal CSCs from human primary colorectal cancers. We obtained 18 surgical specimens of human primary colorectal cancer. CD44, EpCAM, and E-cadherin expression were analyzed by fluorescence-activated cell sorting. Sorted EpCAM ${ }^{\text {high }} / \mathrm{CD} 44^{+}$ colorectal CSCs were injected into immunodeficient mice to estimate the tumorigenic potential. Genetic profiles were analyzed by cDNA microarray. Notably, colorectal CSCs could be divided into two populations based on the E-cadherin expression status, and they exhibited different pathological characteristics. Compared to E-cadherin-negative colorectal CSCs, E-cadherin-positive $\left(\mathrm{EC}^{+}\right)$colorectal CSCs demonstrated higher tumor growth potential in vivo. $\mathrm{EC}^{+}$colorectal CSCs revealed a higher expression of the pluripotency factor NANOG, which contributed to the higher tumor growth potential of $\mathrm{EC}^{+}$colorectal CSCs through control of cyclin D1 expression. These findings are the first demonstration of functionally distinct subpopulations of colorectal CSCs in human clinical samples.
\end{abstract}

Correspondence to: Dr Eishi Baba, Department of Comprehensive Clinical Oncology, Faculty of Medical Sciences, 3-1-1 Maidashi, Higashi-ku, Fukuoka 812-8582, Japan

E-mail: e-baba@c-oncology.med.kyushu-u.ac.jp

Abbreviations: CSC, cancer stem cell; CRC, colorectal cancer; EC, E-cadherin; EMT, epithelial-mesenchymal transition

Key words: cancer stem cell, CD44, colorectal cancer, E-cadherin, NANOG

\section{Introduction}

Solid tumors such as colorectal cancer (CRC) consist of a heterogeneous population of cancer cells. Among these cell populations, cancer stem cells (CSCs) are a limited population that possess self-renewing ability as well as the ability to initiate a heterogeneous tumor in serially transplanted immunodeficient mice. Due to this ability, CSCs are thought to be located at the top of the hierarchy of tumor differentiation (1-3). CSCs are in a quiescent state and have mechanisms to reduce reactive oxidative stress, leading to resistance to chemotherapy or radiotherapy. Furthermore, CSCs change their biological characteristics depending on their microenvironments to develop distant metastasis. CSCs are therefore thought to be responsible for cancer recurrence and metastasis (4-7). Based on these concepts, CSCs are considered to be the most important treatment target to overcome cancers.

Surface markers of CSCs have been explored in the last decade (8-10). The transmembrane glycoprotein CD44, a receptor of hyaluronic acid, is a CSC marker in various cancers $(8,11)$. Dalerba et al revealed that the EpCAM ${ }^{\text {high }} / \mathrm{CD}_{4} 4^{+}$ population of CRC cells has the ability to produce a xenograft tumor in immunodeficient mice, suggesting that these cells may be the CSC population of CRC (12). However, CSC selection according to the expression of CD44 and EpCAM molecules was not sufficient to identify genuine colorectal CSCs since tumor cells with other markers, such as CD133 or ALDH1, also produce xenograft tumors regardless of CD44 expression $(13,14)$. Therefore, additional markers are required to more precisely identify colorectal CSCs.

Recently, Sada et al reported that two molecularly distinct stem cell populations reside in the interfollicular epidermis of adult skin (15). Although these two stem cell populations contribute to maintenance of homeostasis in their territories, they participate in injury repair in both territories. Pathologically distinct populations of CSCs have never been identified in tumors. Since tumors consist of heterogeneous populations, pathologically distinct populations of CSCs may reside in tumors.

E-cadherin is a member of the cadherin superfamily and is preferentially expressed in epithelial cells. E-cadherin mediates cell-cell adhesion through its extracellular domain 
in the presence of calcium ions. In the cytoplasm, E-cadherin is associated with $\alpha-, \beta$ - and p120-catenin, which in turn bind to actin filaments. E-cadherin is not only important for regulation of cell-cell contact, but it also plays a role in regulation of signal transduction pathways via actin filaments. Recently, E-cadherin was reported to be an essential molecule for the self-renewing process of embryonic stem cells (16). In this previous study, it was demonstrated that E-cadherin regulated human embryonic stem cell self-renewal through interaction with Rap1. E-cadherin was also revealed to suppress cancer cell proliferation in CRC (17). $\mathrm{N}$-cadherin is also important for maintenance of stemness of hematopoietic stem cells. Although cadherins are important for maintenance of stem cell properties and cell proliferation, whether E-cadherin regulates stemness and cell proliferation in colorectal CSCs is unclear.

We hypothesized that E-cadherin is essential for the maintenance of properties of colorectal CSCs. We examined the impact of E-cadherin expression on colorectal CSCs using human clinical samples. EpCAM ${ }^{\text {high }} / \mathrm{CD} 44^{+} \mathrm{CSC}$ s contained both E-cadherin-positive $\left(\mathrm{EC}^{+}\right)$and -negative $\left(\mathrm{EC}^{-}\right)$cells Surprisingly, $\mathrm{EC}^{+}$cells exhibited higher tumor growth potential than $\mathrm{EC}^{-}$cells in vivo. Upregulation of NANOG, which is a key molecule for induction of the proliferation of embryonic stem cells, may contribute to the higher tumor growth potential of $\mathrm{EC}^{+}$colorectal CSCs.

\section{Materials and methods}

Patients and tumor tissues. From July 2009 to December 2013, surgical specimens of CRC patients were collected for this study after written informed consent was obtained from patients at Kyushu University Hospital. The study protocol was approved by the Institutional Review Board of Kyushu University Hospital in 2009. In total, 18 samples (from 9 males and 9 females, mean age 64.6 years old) were used for this study and all samples were obtained from the primary site of CRC. As shown in Table I, most cases had well or moderately differentiated adenocarcinomas.

Tumor cell isolation. CRC tissue and normal colon tissue from surgical specimens were mechanically minced into small fragments using a scalpel and scissors in serum-free cell culture medium (RPMI-1640; Wako Pure Chemicals Industries, Ltd., Osaka, Japan). The fragments were enzymatically digested by agitating in HEPES (Wako Pure Chemicals Industries, Ltd.) supplemented with $200 \mathrm{U} / \mathrm{ml}$ collagenase type III (Merck Millipore, Darmstadt, Germany) and $100 \mathrm{U} / \mathrm{ml}$ DNase I (Takara Bio Inc., Shiga, Japan) for $2 \mathrm{~h}$ at $37^{\circ} \mathrm{C}$. The cells were then filtered through $100-\mu \mathrm{m}$ and $40-\mu \mathrm{m}$ nylon meshes, and the remaining cells were resuspended in serum-free medium.

Flow cytometry and cell-sorting experiments. Isolated cancer cells from surgical specimens were resuspended in FCM buffer (HBSS containing 2\% FBS supplemented with $100 \mathrm{U} / \mathrm{ml}$ penicillin, $100 \mu \mathrm{g} / \mathrm{ml}$ streptomycin, $50 \mu \mathrm{g} / \mathrm{ml}$ ceftazidime, $0.25 \mu \mathrm{g} / \mathrm{ml}$ amphotericin-B, $1 \mathrm{mM}$ EDTA, and $1 \mathrm{mM}$ sodium pyruvate) for incubation with fluorescein-labeled antibodies. PE-conjugated anti-CD44 antibody (1:50; cat. no. 561858; BD Biosciences, San Jose, CA, USA) and APC-conjugated anti-EpCAM antibody (1:50; cat. no. 324207; BioLegend, Inc.,
San Diego, CA, USA) were added, and the cells were incubated for $1 \mathrm{~h}$ on ice in the dark. After incubation, the cells were washed twice with PBS and then resuspended in FCM buffer. Flow cytometry was performed using FACSAria II (BD Biosciences, Franklin Lakes, NJ, USA). The viable mononuclear single cell population was gated by forward scatter and propidium iodide staining, and was then sorted with CD44, EpCAM and E-cadherin.

Immunodeficient mice and xenotransplantation. NOD/SCID mice were purchased from The Jackson Laboratory (Bar Harbor, ME, USA). They were housed in groups of 1-4 per cage in a light-controlled room (lights on 7 a.m. to 7 p.m.) at a room temperature of $24 \pm 1^{\circ} \mathrm{C}$ with food and water ad libitum. Forty-six mice (27 males and 19 females) were used. The indicated numbers of sorted tumor cells were resuspended in $200 \mu \mathrm{l}$ BD Matrigel (BD Biosciences, Franklin Lakes, NJ, USA) plus medium. The cell-Matrigel suspension was subcutaneously injected into the opposite flanks of 6-to 8-week-old NOD/SCID mice using a 23-gauge syringe. Tumor formation was observed for up to 6 months. The mice were sacrificed under anesthesia when the tumor size reached a maximum diameter of $20 \mathrm{~mm}$. Xenograft tumors were then isolated from the mice and further analyzed using the same analysis techniques as those used for human colorectal samples or were fixed in $10 \%$ formalin solution. All animal experiments were performed in accordance with the Institutional Animal Welfare Guidelines of Kyushu University.

Immunohistochemistry and immunofluorescence. Formalin-fixed xenograft tumors were cut into $5 \mu \mathrm{m}$-thick serial sections and immunohistochemical studies were performed with avidin-biotin-peroxidase complex kits (Vector Laboratories, Burlingame, CA, USA) according to the manufacturer's instructions. The sections were then counterstained with hematoxylin. For immunofluorescence analysis, the slides were counterstained with DAPI and mounted. The primary antibodies used in this study were: Anti-E-cadherin (1:50; cat. no. sc-31021; Santa Cruz Biotechnology, Inc., Santa Cruz, Dallas, TX, USA), anti-CD44 (1:100; cat. no. 550538; BD Biosciences, San Jose, CA, USA), and anti-NANOG (1:100; cat. no. 4903; Cell Signaling Technology, Danvers, MA, USA).

mRNA isolation and cDNA array. Total RNA was isolated from both $\mathrm{EC}^{+}$cells and $\mathrm{EC}^{-}$cells, using TRIzol (Invitrogen; Thermo Fisher Scientific, Inc., Carlsbad, CA, USA) and was purified using the SV Total RNA Isolation System (Promega Corp., Madison, WI, USA), according to the manufacturer's instructions. The quality and quantity of the RNA samples obtained were verified using the Experion System (Bio-Rad Laboratories, Hercules, CA, USA) and an ND-1000 Spectrophotometer (NanoDrop Technologies; Thermo Fisher Scientific, Inc., Wilmington, DE, USA). The cRNA was amplified, labeled, and hybridized to a 60K Agilent 60-mer oligomicroarray according to the manufacturer's instructions. All hybridized microarray slides were scanned using an Agilent scanner (Agilent Technologies, Santa Clara, CA, USA). Relative hybridization intensities and background hybridization values were calculated using Agilent Feature Extraction Software (version 9.5.1.1). Raw signal intensities and flags 
for each probe were calculated from hybridization intensities (gProcessedSignal), and spot information (gIsSaturated) according to the procedures recommended by Agilent. The raw signal intensities of two samples were $\log _{2}$-transformed and normalized using a quantile algorithm with the 'preprocessCore' library package (18) on Bioconductor software (19). We selected probes that called a 'P' flag in both samples. To identify upregulated or downregulated genes, we calculated $\mathrm{Z}$-scores (20) and ratios (non-log scaled fold-change) from the normalized signal intensities of each probe for comparison between the control and experimental samples. We then established the following criteria for regulated genes: (upregulated genes) $Z$-score $\geq 2.0$ or ratio $\geq 1.5$-fold, (downregulated genes) Z-score $\leq-2.0$ or ratio $\leq 0.66$.

RNA interference for NANOG. Pre-designed NANOG siRNA was purchased from Thermo Fisher Scientific, Inc. (Waltham, MA, USA). HCT116 cells were seeded in 35-mm dishes and transfected with control siRNA or NANOG siRNA using Lipofectamine 3000 according to the manufacturer's instructions (Thermo Fisher Scientific, Inc.). Ninety-six hours after transfection, the cells were collected and analyzed for NANOG mRNA expression with RT-qPCR and NANOG protein with an immunofluorescence study. For the cell proliferation assay, $1 \times 10^{3}$ cells were seeded in $35-\mathrm{mm}$ dishes $72 \mathrm{~h}$ after transfection, and then the number of viable cells was counted on days 1-5.

RT-PCR and quantitative RT-PCR. Ninety-six hours after transfection, total RNA was extracted from the siRNA-transfected cells using TRIzol (Invitrogen; Thermo Fisher Scientific, Inc.), and $2 \mu \mathrm{g}$ total RNA was used for first-strand cDNA synthesis using SuperScript ${ }^{\mathrm{TM}}$ IV VILO ${ }^{\mathrm{TM}}$ Master Mix (Invitrogen; Thermo Fisher Scientific, Inc.), according to the manufacturer's instructions. RT-PCR was performed using TaKaRa Ex Taq ${ }^{\circledR}$ (Takara Bio Inc.) and the Gene Amp PCR System 9,700 (Thermo Fisher Scientific, Inc.) at the following cycling conditions: 29 cycles of $30 \mathrm{sec}$ at $94^{\circ} \mathrm{C}, 30 \mathrm{sec}$ at $60^{\circ} \mathrm{C}$ and $60 \mathrm{sec}$ at $72^{\circ} \mathrm{C}$. Quantitative RT-PCR was performed using SYBR ${ }^{\circledR}$ Premix Ex Taq ${ }^{\mathrm{TM}}$ II (Takara Bio Inc.) and StepOnePlus Real-Time PCR Systems (Thermo Fisher Scientific, Inc.). PCR was performed in triplicate.

Results are expressed as the NANOG copy number normalized to $10^{4} \mathrm{GAPDH}$. Gene specific primers used in this study were: NANOG forward, 5'-TGCAGAGAAGAG TGTCGCAA-3' and reverse, 5'-CAGGTCTTCACCTGTTTG TAGC-3'; NANOG (qPCR) forward, 5'-GGTGTGACGCAG AAGGCCTCA-3' and reverse, 5'-CCCAGTCGGGTTCAC CAGGCA-3'; cyclin D1 forward, 5'-AGCTCCTGTGCTGCG AAGTGGAAAC-3' and reverse, 5'-AGTGTTCAATGAAAT CGTGCGGGGT-3'; cyclin A forward, 5'-CCTGCTCGTCAC TTGGGATG-3' and reverse, 5'-ACTGTAGCCAGCACAACT CC-3'; cyclin B1 forward, 5'-GCCTGCAAATGCCTGGTT TAT-3' and reverse, 5'-GCCACAGCCTTGGCTAAATC-3'; cyclin E forward, 5'-TGGCGTTTAAGTCCCCTGAC-3' and reverse, 5'-TCAGTTTTGAGCTCCCCGTC-3'; p21 forward, 5'-AGTACCCTCTCAGCTCCAGG-3' and reverse, 5'-TGT CTGACTCCTTGT-3' p27 forward, 5'-TGTCAAACGTGC GAGTGTCT-3' and reverse, 5'-TGTCCTCAGAGTTAGCCG GA-3'; GAPDH forward, 5'-ACCCAGAAGACTGTGGAT GG-3' and reverse, 5'-TCTAGACGGCAGGTCAGGTC-3'.
Table I. Patient characteristics.

\begin{tabular}{rrrrll}
\hline No. & Age & Sex & Primary site & Histology & Stage $^{\mathrm{a}}$ \\
\hline$\# 6$ & 42 & $\mathrm{M}$ & $\mathrm{R}$ & Mod & IIIA \\
$\# 7$ & 51 & $\mathrm{M}$ & $\mathrm{T}$ & Well to mod & I \\
$\# 8$ & 83 & $\mathrm{M}$ & $\mathrm{A}$ & Mod to poor & IVA \\
$\# 24$ & 77 & $\mathrm{M}$ & $\mathrm{R}$ & Well & IIA \\
$\# 44$ & 43 & $\mathrm{~F}$ & $\mathrm{R}$ & Mod & IIA \\
$\# 49$ & 60 & $\mathrm{M}$ & $\mathrm{T}$ & Mod & IIA \\
$\# 50$ & 72 & $\mathrm{~F}$ & $\mathrm{C}$ & Poor & IIB \\
$\# 58$ & 78 & $\mathrm{~F}$ & $\mathrm{~S}$ & Mod & IIA \\
$\# 62$ & 77 & $\mathrm{~F}$ & $\mathrm{~A}$ & Well & IVA \\
$\# 63$ & 43 & $\mathrm{~F}$ & $\mathrm{~A}$ & Well to mod & IIIC \\
$\# 64$ & 74 & $\mathrm{M}$ & $\mathrm{A}$ & Well to mod & IIA \\
$\# 70$ & 58 & $\mathrm{M}$ & $\mathrm{S}$ & Well & IIA \\
$\# 71$ & 63 & $\mathrm{~F}$ & $\mathrm{R}$ & Well to mod & IIA \\
$\# 74$ & 72 & $\mathrm{~F}$ & $\mathrm{D}$ & Mod & IIA \\
$\# 180$ & 72 & $\mathrm{M}$ & $\mathrm{A}$ & Well to Mod & IIIB \\
$\# 182$ & 61 & $\mathrm{~F}$ & $\mathrm{C}$ & Well & IIIB \\
$\# 187$ & 73 & $\mathrm{~F}$ & $\mathrm{C}$ & Poor & IIIC \\
$\# 211$ & 63 & $\mathrm{M}$ & $\mathrm{R}$ & Well & IIIC \\
& & & & & \\
\hline
\end{tabular}

${ }^{a}$ UICC TNM classification. $\mathrm{M}$, male; $\mathrm{F}$, female; $\mathrm{C}$, cecum; $\mathrm{A}$, ascending colon; T, transverse colon; D, descending colon; R, rectum; Well, well-differentiated adenocarcinoma; Mod, moderately differentiated adenocarcinoma; Poor, poorly differentiated adenocarcinoma.

Statistical analysis. Results are expressed as the mean $\pm \mathrm{SE}$ unless otherwise stated. Student's t-test was used to evaluate statistical significance. Values of $\mathrm{P}<0.05$ were considered to indicate a statistically significant difference.

\section{Results}

The EpCAM $\mathrm{M}^{\text {high }} / \mathrm{CD} 44^{+}$population in CRC has tumor-initiating potential in immunodeficient mice. We examined surgically resected colorectal tumors from 18 patients (Table I). Fifteen patients had clinical stage II or III disease, and two cases had clinical stage IV disease. Pathologically, most patients had well or moderately differentiated adenocarcinomas. We isolated the cancer cells enzymatically and sorted cells using anti-CD44 and anti-EpCAM antibodies as previously reported (12). Fluorescence-activated cell sorting analysis indicated that colorectal tumors contained both an EpCAM ${ }^{\text {high }} / \mathrm{CD}_{4} 4^{+}$ population and an EpCAM ${ }^{\text {positive }} / \mathrm{CD}^{-} 4^{-}$population of cells (Fig. 1A). To confirm that the EpCAM ${ }^{\text {high }} / \mathrm{CD} 44^{+}$population had tumorigenic potential in vivo, we transplanted $4 \times 10^{3}$ $\mathrm{EpCAM}^{\text {high }} / \mathrm{CD} 44^{+}$cells or $1 \times 10^{4} \mathrm{EpCAM}^{\text {positive }} / \mathrm{CD} 44^{-}$cells subcutaneously into NOD/SCID mice. As shown in Fig. 1B, EpCAM ${ }^{\text {high }} / \mathrm{CD} 44^{+}$cells produced tumors ( $n=3$, patients \#6-8), but no tumor was observed in mice in whichEpCAM ${ }^{\text {positive }} / \mathrm{CD} 44$ cells had been transplanted $(n=3$, patients \#6-8). This result revealed that EpCAM ${ }^{\text {high }} / \mathrm{CD} 44^{+} \mathrm{CRC}$ cells have tumorigenic potential in vivo.

Next, we investigated CD44 expression in the xenograft tumors by flow cytometric analysis to examine whether the 
A

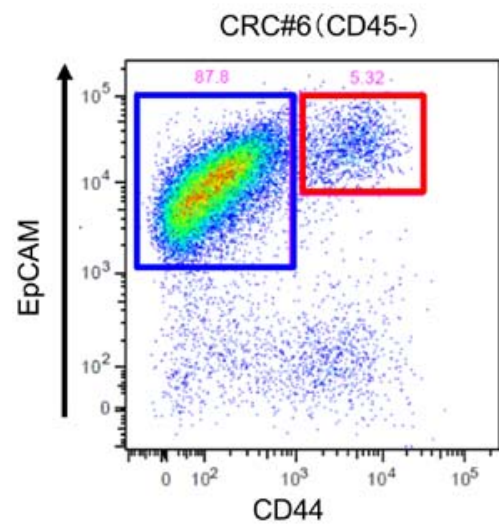

B

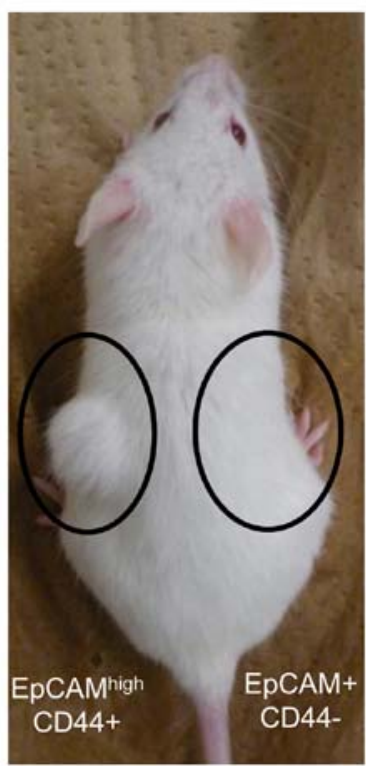

C

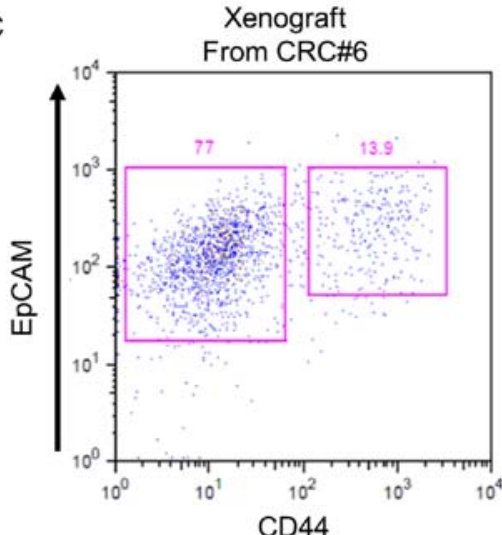

D

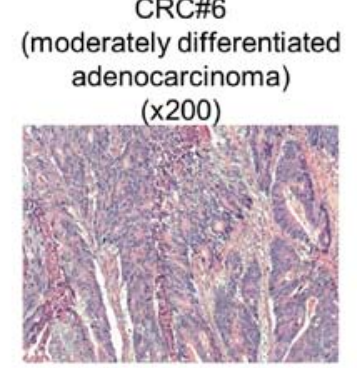

\section{Xenograft tumor from CRC\#6} $(x 200)$

E 1

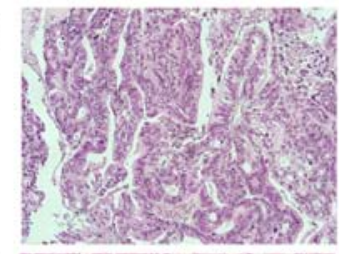

3

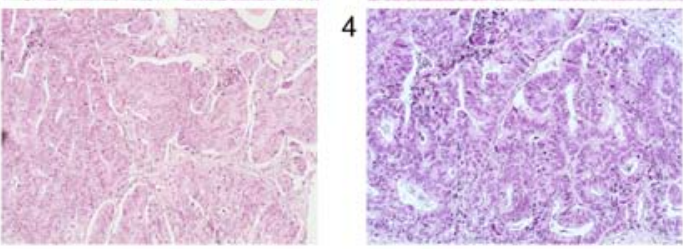

Xenograft tumor from CRC\#7 (x200)

Figure 1. Tumorigenic potential of EpCAM ${ }^{\text {high }} / \mathrm{CD} 44^{+}$colorectal cancer cells in vivo. (A) Flow cytometric analysis of a human colorectal cancer. A small $\mathrm{EpCAM}^{\text {high }} / \mathrm{CD} 44^{+}$population was detected in the human colorectal cancer. (B) Only EpCAM ${ }^{\text {high }} / \mathrm{CD} 44^{+}$cells had tumorigenic potential in NOD/SCID mice. (C) Flow cytometric analysis of a xenograft tumor. $\mathrm{EpCAM}^{\text {high }} / \mathrm{CD}_{4} 4^{+}$cells gave rise to $\mathrm{EpCAM}^{\text {positive }} / \mathrm{CD}^{-} 4^{-}$cells and reconstituted the expression profiles of the primary sample. (D) H\&E staining of a primary and a xenograft tumor. The histology of the xenograft tumor was the same as that of the primary tumor. (E) Serial transplantation recapitulated the histology of the primary tumors.

EpCAM ${ }^{\text {high }} / \mathrm{CD} 44^{+}$population had the ability to self-renew and reconstitute a heterogeneous tumor. Xenograft tumors derived from EpCAM ${ }^{\text {high }} / \mathrm{CD} 44^{+}$cells consisted of both the EpCAM $^{\text {high }} / \mathrm{CD}_{4} 4^{+}$population and the EpCAM ${ }^{\text {positive }} / \mathrm{CD} 44$ population (Fig. 1C). We also examined the histological type of the xenograft tumors. H\&E staining of a xenograft tumor revealed abnormal ductal morphogenesis, indicating that it was a moderately differentiated adenocarcinoma, which was the same histological type as the primary human CRC (Fig. 1D). These xenograft tumors therefore histologically were the same as the primary tumors. In addition, the EpCAM ${ }^{\text {high }} / \mathrm{CD} 44^{+}$ population from the xenograft tumor could produce tumors that exhibited the same histology as human CRC in serially transplanted mice. Thus, we repeated transplantation four times, and each time, the tumor that developed exhibited the same histology (Fig. 1E). These results indicated that $\mathrm{EpCAM}^{\text {high }} / \mathrm{CD} 44^{+} \mathrm{CRC}$ cells possess the ability to self-renew and produce heterogeneous tumors with the same histology as the primary tumor in vivo.

The EpCAM ${ }^{\text {high }} / C D 44^{+}$population expresses E-cadherin, but not $N$-cadherin. E-cadherin is essential for the self-renewal ability of embryonic stem cells $(16,21)$. In addition, $\mathrm{N}$-cadherin is important to maintain stemness in hematopoietic stem cells (22). We hypothesized that cadherin superfamily members may play a role in maintaining the stemness of colorectal CSCs. First, we sorted EpCAM ${ }^{\text {high }} / \mathrm{CD}_{4} 4^{+}$and EpCAM $^{\text {positive }} / \mathrm{CD}^{-} 4^{-}$populations and examined E-cadherin expression in the EpCAM ${ }^{\text {high }} / \mathrm{CD} 44^{+}$population using flow cytometric analysis; $15.8 \%$ of these $\mathrm{EpCAM}^{\mathrm{high}} / \mathrm{CD} 44^{+}$ cells expressed E-cadherin (10.8-20.0\%; n=3; Fig. 2A). Immunohistochemical staining indicated that CD44-positive cells in atypical ducts expressed E-cadherin (Fig. 2B, red arrow), but that E-cadherin was downregulated in CD44-positive cells 
A

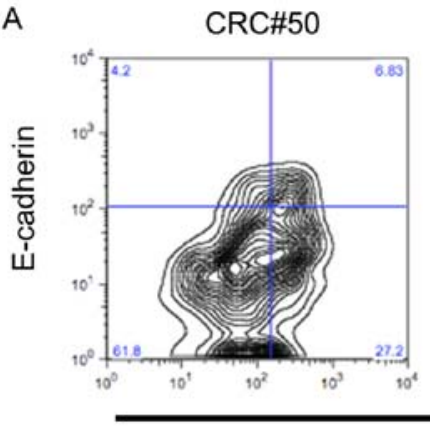

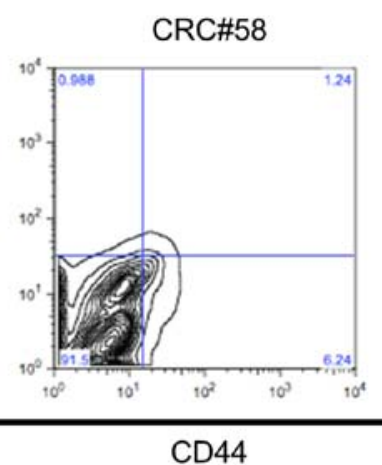
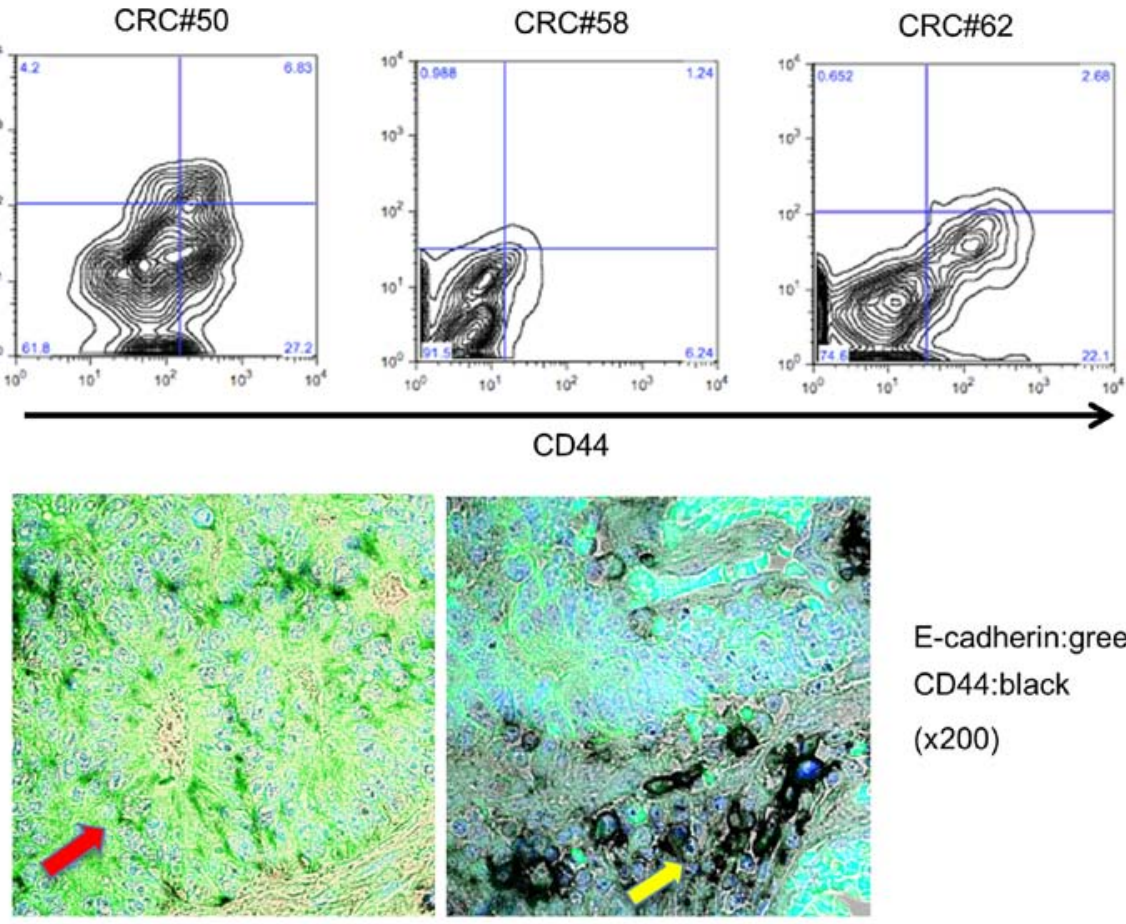

E-cadherin:green CD44:black

$(\times 200)$

CRC\#62

C
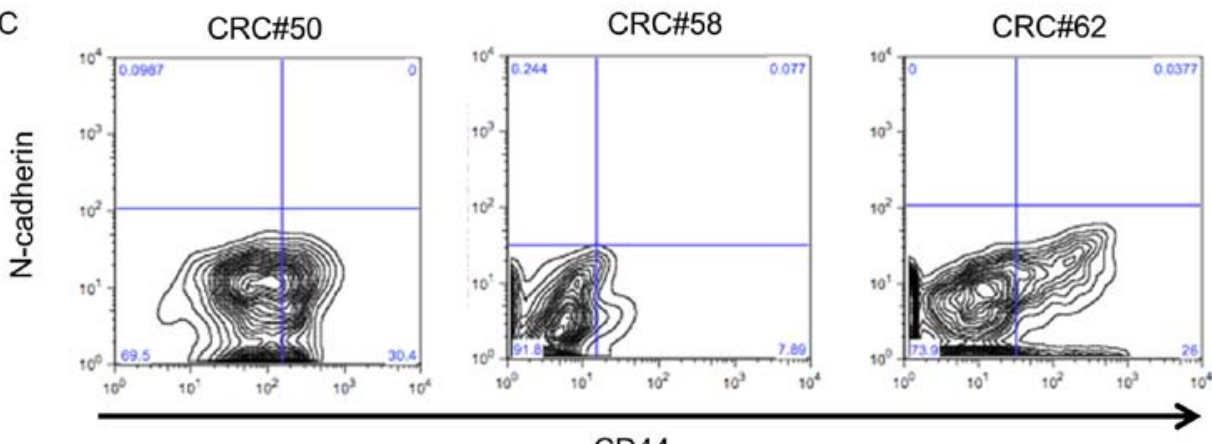

CD44

Figure 2. E-cadherin expression in EpCAM ${ }^{\text {high }} / \mathrm{CD} 44^{+}$colorectal cancer cells. (A) EpCAM $\mathrm{M}^{\text {high }} / \mathrm{CD} 44^{+}$colorectal cancer cells contained an E-cadherin ${ }^{+}$ and an E-cadherin population. (B) Immunohistochemical staining of a human colorectal cancer specimen. The red arrow indicates CD44 (black) and E-cadherin (green) double-positive cells. The yellow arrow indicates CD44 (black) positive but E-cadherin negative cells. (C) N-cadherin was not expressed in $\mathrm{EpCAM}^{\text {high }} / \mathrm{CD}_{4} 4^{+}$colorectal cancer cells.

in the tumor invasive area (Fig. 2B, yellow arrow). Since a previous study revealed that cancer cells that had undergone epithelial-mesenchymal transition (EMT) had CSC properties (23), EC ${ }^{-} \mathrm{EpCAM}^{\text {high }} / \mathrm{CD} 44^{+}$cells were hypothesized to express $\mathrm{N}$-cadherin, which is a marker of EMT. We next examined $\mathrm{N}$-cadherin expression in the EpCAM ${ }^{\text {high }} / \mathrm{CD} 44^{+}$ cells using flow cytometry. As shown in Fig. 2C, N-cadherin expression was not observed in EpCAM ${ }^{\text {high }} / \mathrm{CD} 44^{+}$cells from primary human tumors $(0-0.97 \%$; $=3$; Fig. $2 \mathrm{C})$. These results revealed that EpCAM ${ }^{\text {high }} / \mathrm{CD} 44^{+}$cells could be divided into two populations based on E-cadherin expression status and that EMT may not be related to E-cadherin downregulation in EpCAM ${ }^{\text {high }} / \mathrm{CD}_{4} 4^{+}$cells in primary human colorectal tumors.

E-cadherin expressing EpCAM $M^{\text {high }} / C D 44^{+}$cells have higher tumorigenic potential in vivo. To investigate differences in the pathological phenotype between $\mathrm{EC}^{+} \mathrm{EpCAM}^{\text {high }} / \mathrm{CD} 44^{+}$ cells and $\mathrm{EC}^{-} \mathrm{EpCAM}^{\mathrm{high}} / \mathrm{CD} 44^{+}$cells, we isolated each cell population from human primary colorectal tumors and transplanted the isolated cells subcutaneously into NOD/SCID mice ( $n=7$, patients \#44, 49, 63, 64, 70, 71 and 74). Ten weeks after injection, four out of the eight mice that were injected with more than $3 \times 10^{3} \mathrm{EC}^{+} \mathrm{EpCAM}^{\text {high }} / \mathrm{CD}_{4} 4^{+}$cells bore tumors. In particular, three of the four tumors originated from patient \#49, and one originated from patient \#63. In contrast, one of the six mice had a xenograft tumor after injection of $3 \times 10^{3} \mathrm{EC}^{-} \mathrm{EpCAM}^{\text {high }} / \mathrm{CD} 44^{+}$cells from patient \#63 (Table II and Fig. 3A). However, no statistically significant difference was found in terms of tumorigenicity, because only one of the five mice bore a tumor when $3 \times 10^{3} \mathrm{EC}^{+}$ EpCAM ${ }^{\text {high }} / \mathrm{CD}_{4} 4^{+}$cells were injected $(\mathrm{P}=0.297)$.

Then, we hypothesized that $\mathrm{EC}^{+}$cells from xenograft tumors may have a higher tumorigenic potential in vivo. To assess this, we isolated $\mathrm{EC}^{+}$and $\mathrm{EC}^{-}$cells from xenograft tumors that originated from patients \#8, 49, 50 and 62 and injected them into immunodeficient mice. Both $\mathrm{EC}^{+}$and 
Table II. Tumor-initiating potential of E-Cadherin ${ }^{+}$and - cells within the EpCAM ${ }^{\text {high }} / \mathrm{CD} 44^{+}$population in vivo.

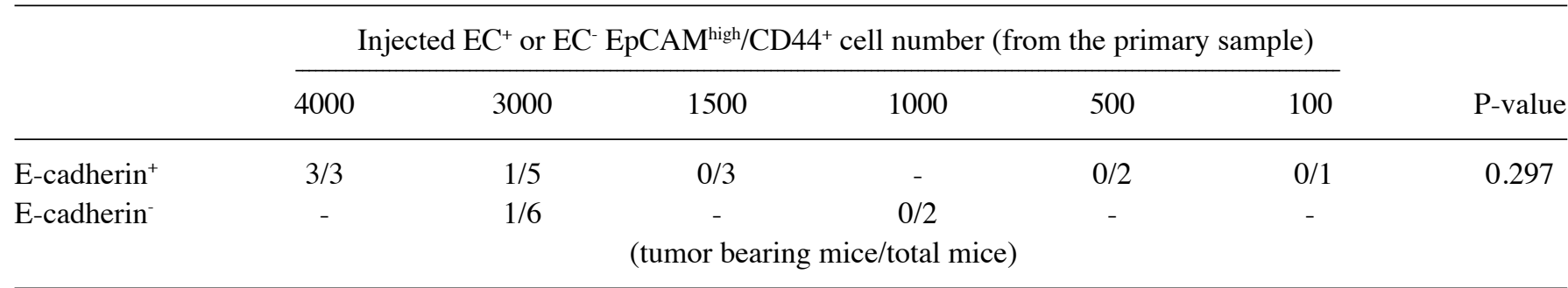

Injected $\mathrm{EC}^{+}$or $\mathrm{EC}^{-} \mathrm{EpCAM}^{\text {high }} / \mathrm{CD} 44^{+}$cell number (from the xenograft tumor)

\begin{tabular}{lccccccr} 
& 5000 & 4000 & 3000 & 2000 & 1000 & 100 & P-value \\
\cline { 2 - 6 } & - & $1 / 1$ & $6 / 6$ & $0 / 1$ & $2 / 3$ & $0 / 1$ & 0.099 \\
E-cadherin $^{+}$ & $1 / 3$ & $1 / 1$ & $3 / 3$ & $1 / 1$ & $1 / 1$ & - & \\
E-cadherin $^{-}$ & & & (tumor bearing mice/total mice) & & & \\
& & & &
\end{tabular}

A
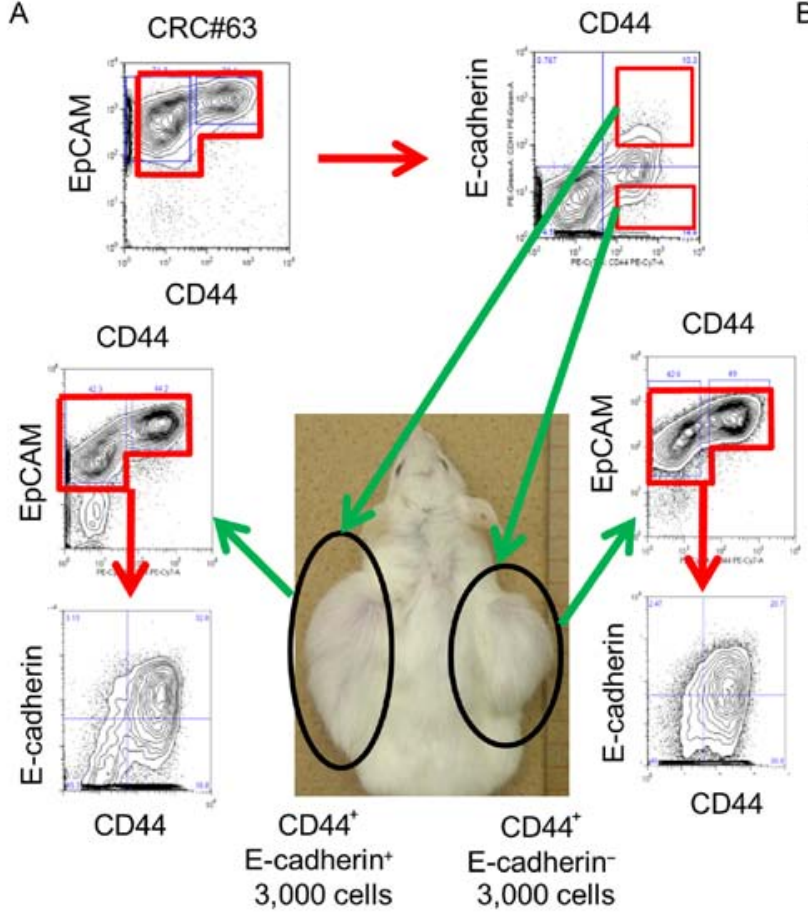

B

Tumor

(g)

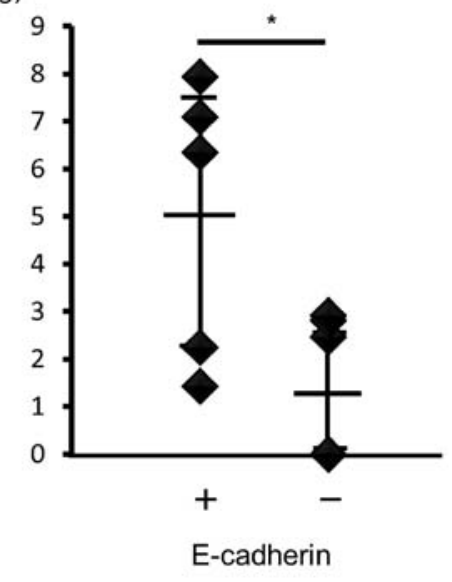

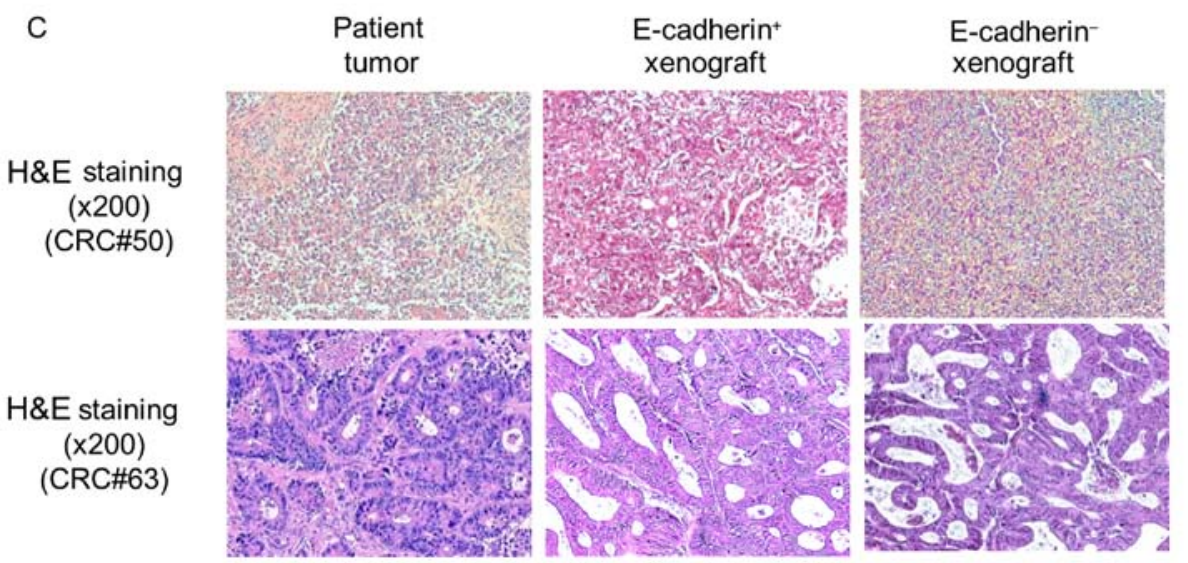

Figure 3. Higher tumorigenic potential of E-cadherin ${ }^{+}$colorectal CSCs. (A) Image of a mouse bearing a xenograft tumor from $\mathrm{EC}^{+}$and $\mathrm{EC}^{-}$colorectal CSCs and flow cytometric analyses of their phenotype. (B) Tumor weight of xenograft tumors. Error bars represent the $95 \%$ confidence interval. $\mathrm{EC}^{+}$colorectal CSCs produced significantly larger tumors compared to $\mathrm{EC}^{-}$colorectal CSCs. ${ }^{*} \mathrm{P}<0.01$ (C) Histopathological analysis of xenograft tumors from $\mathrm{EC}^{+} \mathrm{CSCs}$ and EC CSCs. 
A

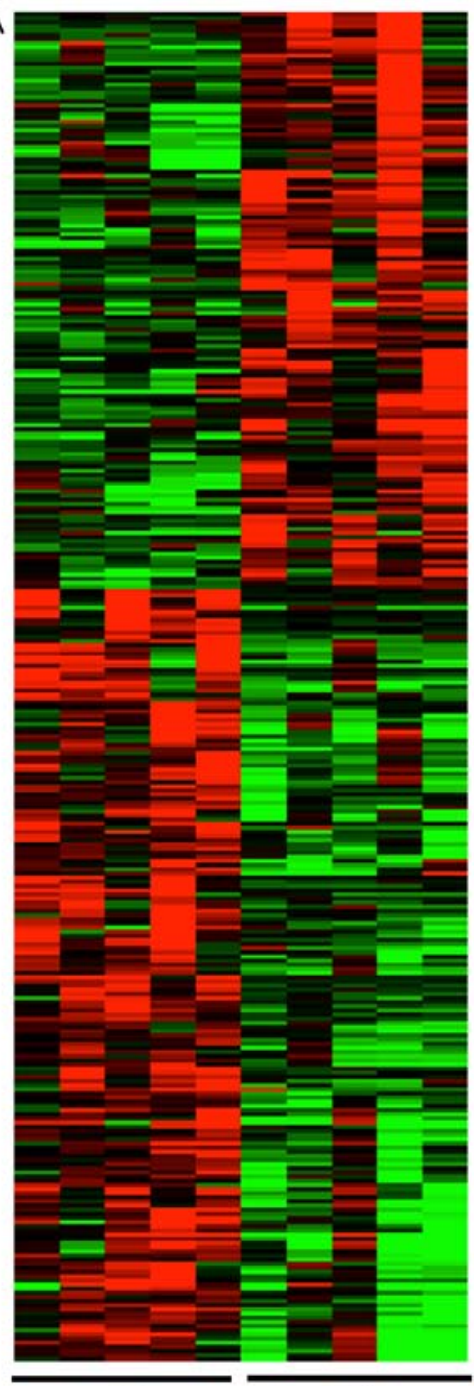

EC-

$\mathrm{EC}^{+}$
B

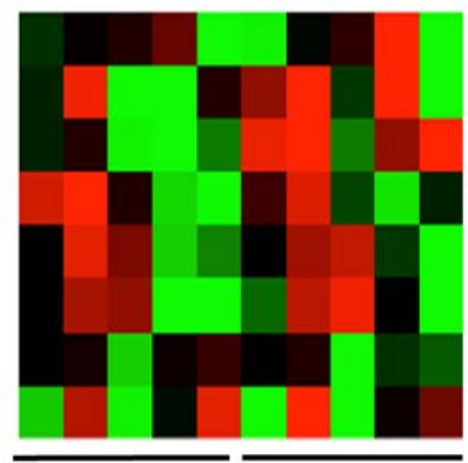

C
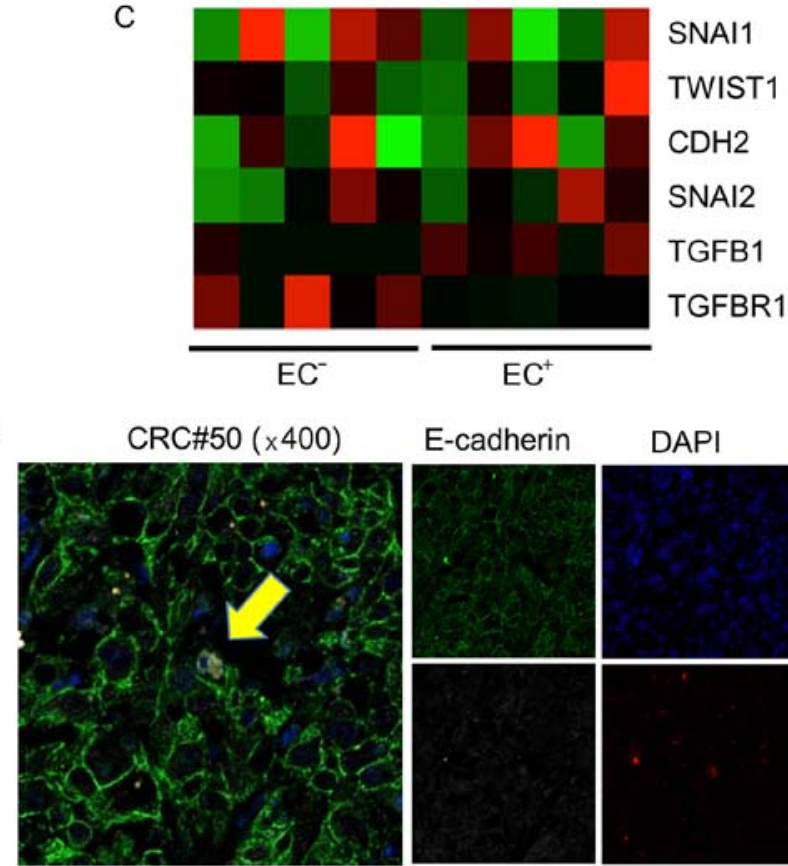

$\mathrm{EC}^{+}$

POU5F1

SOX6

NANOG

BMP7

MYC

SOX2

KLF4

$\mathrm{CDX} 2$

NAI1

TWIST1

$\mathrm{CDH} 2$

SNAI2

GFBR1

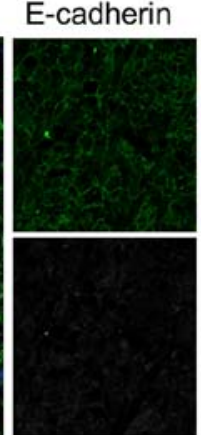

NANOG
DAPI

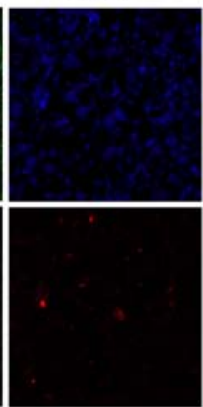

CD44

Figure 4. Upregulation of $N A N O G$ expression in $\mathrm{EC}^{+} \mathrm{CSCs}$. cDNA microanalysis of (A) total gene expression, (B) transcription-related (including $N A N O G$ ) gene expression, and (C) EMT-related gene expression in $\mathrm{EC}^{+}$and $\mathrm{EC}^{-} \mathrm{CSCs}$. (A) Total gene expression differed between $\mathrm{EC}^{+} \mathrm{CSC}$ s and $\mathrm{EC}^{-} \mathrm{CSCs}^{-}$(B) $N A N O G$ expression was significantly upregulated in $\mathrm{EC}^{+} \mathrm{CSCs}$ vs. $\mathrm{EC}^{-} \mathrm{CSC}$. (C) Expression of genes related to EMT did not differ between $\mathrm{EC}^{+} \mathrm{CSCs}$ and $\mathrm{EC}^{-} \mathrm{CSCs}^{-}$ (D) Immunofluorescence staining of a human colorectal cancer specimen. NANOG was expressed in the nucleus of CD44 and E-cadherin double-positive colorectal cancer cells (yellow arrow).

EC $^{-}$cells from xenograft tumors exhibited higher tumorigenic potential compared to cells from primary tumors. All mice that had been injected with more than $3 \times 10^{3} \mathrm{EC}^{+}$cells bore tumors. In addition, two of the three mice bore tumors after $1 \times 10^{3} \mathrm{EC}^{+}$cells were injected. In contrast, five of the seven mice that had been injected with more than $3 \times 10^{3} \mathrm{EC}^{-}$cells had tumors (Table II). We did not detect a significant difference regarding tumorigenicity in this setting $(\mathrm{P}=0.099)$.

Although both $\mathrm{EC}^{+}$and $\mathrm{EC}^{-}$cells exhibited tumorigenic potential in vivo, $\mathrm{EC}^{+}$cells produced significantly larger and heavier tumors. The average weight of a tumor derived from $\mathrm{EC}^{+}$cells was $5.01 \mathrm{~g}(1.43-7.94 \mathrm{~g}, \mathrm{n}=5)$, whereas that derived from $\mathrm{EC}^{-}$cells was $1.64 \mathrm{~g}(0.00-2.92 \mathrm{~g}, \mathrm{n}=5, \mathrm{P}=0.026$; Fig. 3B). $\mathrm{H} \& \mathrm{E}$ staining of xenograft tumors derived from $\mathrm{EC}^{+}$or $\mathrm{EC}^{-}$ cells revealed that the tumors had the same histology (Fig. 3C). Based on these results, $\mathrm{EC}^{+} \mathrm{EpCAM}^{\text {high }} / \mathrm{CD} 44^{+}$cells had higher tumor growth potential in vivo compared to $\mathrm{EC}^{-}$ EpCAM $^{\text {high }} / \mathrm{CD} 44^{+}$cells.
cDNA microarray identifies genes potentially related to the higher tumor growth ability of $\mathrm{EC}^{+} \mathrm{EpCAM}$ high $/ \mathrm{CD}^{4} 4^{+}$cells. To explore the genetic profile leading to the difference in tumor growth potential between $\mathrm{EC}^{+}$and $\mathrm{EC}^{-} \mathrm{EpCAM}^{\text {high }} / \mathrm{CD}_{4} 4^{+}$ cells, we isolated $5 \times 103 \mathrm{EC}^{+}$and $\mathrm{EC}^{-} \mathrm{EpCAM}^{\text {high }} / \mathrm{CD} 44^{+}$cells from primary tumors of patients \#24, 180, 182, 187, and 211, and analyzed the mRNA expression of 41,628 genes using a cDNA microarray (Agilent Technologies, Santa Clara, CA, USA). Different gene expression profiles were obtained for the $\mathrm{EC}^{+}$and $\mathrm{EC}^{-}$EpCAM ${ }^{\text {high }} / \mathrm{CD} 44^{+}$cells (Fig. 4A). We subsequently focused on NANOG expression since NANOG is a transcription factor that is essential for self-renewal and pluripotency of embryonic stem cells. Moreover, NANOG has been revealed to be associated with increased cell proliferation in the colon (24). In four out of five populations of $\mathrm{EC}^{+}$ cells, NANOG expression was upregulated more than four times, compared to EC ${ }^{-}$cells. The expression of CDX2, which is a crypt-like differentiation marker, was not upregulated in 
A

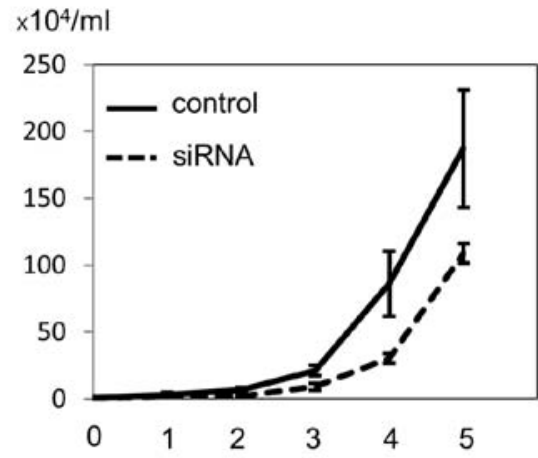

C

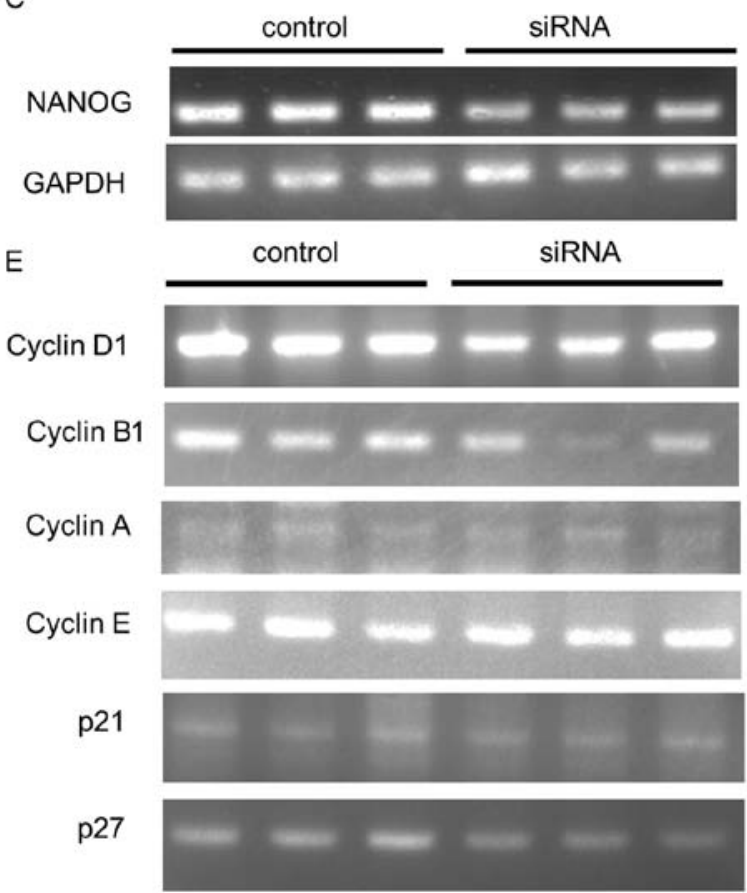

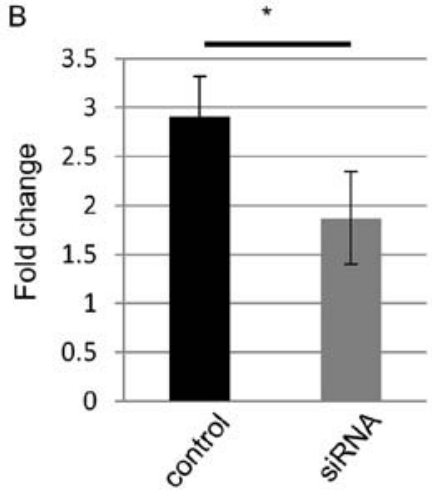

D NANOG:green, CD44:red DAPI:blue $(x 200)$

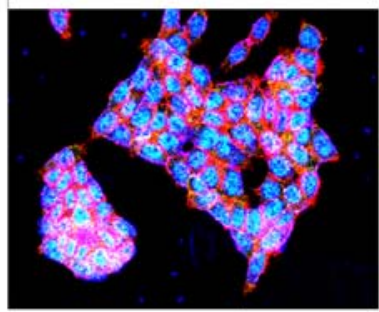

control

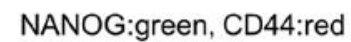
DAPI:blue $(x 200)$

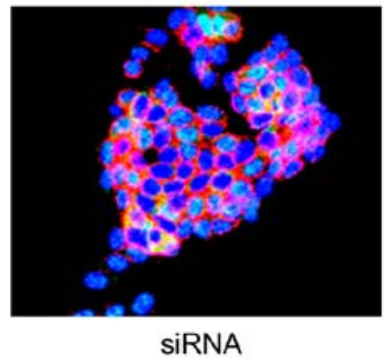

Figure 5. NANOG regulates colorectal cancer cell proliferation through the control of cyclin D1 expression. (A) Growth curve of HCT116 colorectal cancer cells. NANOG siRNA-transfected cells exhibited decreased cell proliferation compared to the control. (B) Quantitative RT-PCR ("P<0.01) and (C) RT-PCR identified NANOG suppression in siRNA-transfected cells. (D) An immunofluorescence study revealed the downregulation of NANOG protein after siRNA transfection. (E) RT-PCR for cyclins. Cyclin D1 and cyclin B1 mRNA levels were decreased in siRNA-transfected cells, but the expression levels of other cyclins, p21, and p27 were not changed.

EC ${ }^{-}$cells (Fig. 4B, Table III). We then compared the expression of EMT-related genes between $\mathrm{EC}^{+}$cells and $\mathrm{EC}^{-}$cells. Consistent with previous data, EMT-related gene expression was not different between the cell types, and the CDH1 mRNA level was not altered (Fig. 4C, Table III). Next, we confirmed the expression of NANOG in EpCAM ${ }^{\text {high }} / \mathrm{CD} 44^{+}$cells using immunofluorescence. NANOG expression was detected in the nucleus of one of eight $\mathrm{EC}^{+} \mathrm{EpCAM}^{\text {high }} / \mathrm{CD} 44^{+}$cells (Fig. 4D).

These results revealed that NANOG may be involved in the higher tumor growth ability of $\mathrm{EC}^{+} \mathrm{CSC}$ cells, but was not associated with CSC properties or EMT in colorectal CSCs.

NANOG increases CSC proliferation through cyclin DI expression. To confirm that NANOG-induced higher cell proliferation ability in $\mathrm{EC}^{+}$colorectal CSCs, we knocked out NANOG expression in the HCT116 CRC cell line with siRNA, since this cell line expresses CD44, a colorectal CSC marker, and NANOG. As expected, NANOG siRNA-transfected cells demonstrated lower cell proliferation ability than control siRNA-transfected cells (Fig. 5A). To confirm the knockout of NANOG, we estimated NANOG mRNA levels with RT-qPCR 4 days after transfection. Compared to the control siRNA-transfected cells, the NANOG mRNA level was significantly decreased in NANOG siRNA-transfected cells (Fig. 5B). In addition, our RT-PCR analysis also revealed downregulation of $N A N O G$ mRNA expression (Fig. 5C).

We performed an immunofluorescence study to confirm NANOG protein downregulation. All control HCT116 cells expressed NANOG protein in the nucleus, and we could not detect NANOG protein in some siRNA-transfected cells 4 days after transfection (Fig. 5D).

Next, we analyzed the mechanism of the decreased proliferation ability induced by downregulation of NANOG. Since NANOG regulates cell cycle-related gene expression $(25,26)$, we hypothesized that the lower cell proliferation ability may be due to cyclin D1 downregulation after knockout of NANOG. We analyzed mRNA expression of cell cycle-related genes 4 days after siRNA transfection. RT-PCR data revealed 
Table III. The relative ratio of mRNA expression of stemness and EMT-related genes between $\mathrm{EC}^{+}$and $\mathrm{EC}^{-}$cells $\left(\mathrm{EC}^{+} / \mathrm{EC}^{-}\right)$.

A, Transcription-related gene expression

\begin{tabular}{|c|c|c|c|c|c|}
\hline & \#180 (ratio) & \#182 (ratio) & \#187 (ratio) & \#211 (ratio) & \#24 (ratio) \\
\hline POU5F1 & 0.349898 & 0.904157 & 1.078143 & 3.702691 & NULL \\
\hline NANOG & 4.328553 & 4.141721 & 1.860814 & 21.28952 & 9.054102 \\
\hline SOX2 & 0.562313 & 1.136609 & 1.654131 & 14.43825 & NULL \\
\hline SOX6 & 2.599258 & 2.951994 & 4.416502 & 23.84684 & 0.202682 \\
\hline KLF4 & 1.024759 & 1.106549 & 0.699897 & 0.709549 & 0.464341 \\
\hline BMP7 & 0.453347 & 0.583328 & 0.563205 & NULL & NULL \\
\hline $\mathrm{CDX} 2$ & 0.270185 & 1.509952 & 0.248415 & 1.154388 & 0.536948 \\
\hline
\end{tabular}

B, EMT-related gene expression

\begin{tabular}{|c|c|c|c|c|c|}
\hline & \#180 (ratio) & \#182 (ratio) & \#187 (ratio) & \#211 (ratio) & \#24 (ratio) \\
\hline CDH1 & 0.959147 & 0.904071 & 1.285291 & 1.474868 & 0.747187 \\
\hline $\mathrm{CDH} 2$ & NULL & 1.330456 & 7.381092 & 0.046765 & NULL \\
\hline SNAI1 & 1.326144 & 0.513009 & 0.849582 & 0.241307 & 1.678008 \\
\hline SNAI2 & 1.325459 & 2.02312 & 0.837368 & 1.275875 & 1.118609 \\
\hline TWIST1 & NULL & NULL & NULL & NULL & NULL \\
\hline
\end{tabular}

that cyclin D1 mRNA levels were decreased in NANOG siRNA-transfected cells. In addition, cyclin B1 mRNA levels were also decreased, especially in one siRNA-transfected cell line, but mRNA levels of other cyclins, p21, and p27 were not altered (Fig. 5E).

These data revealed that NANOG increased CRC cell proliferation through up-regulation of cyclin D1, and that cyclin B1 may also be involved in this process. In particular, NANOG controlled colorectal CSC proliferation, leading to the difference in the tumor growth rate between $\mathrm{EC}^{+} \mathrm{CSC}$ and EC- CSCs (Fig. 6).

\section{Discussion}

The classical understanding of the concept of CSCs is that tumor tissue arises from CSCs and that a limited population of tumor cells during tumor growth has CSC properties. The CSC population is considered to be uniform because it is small in numbers. However, cancer cells that undergo EMT also possess CSC properties (23), and this EMT-induced stemness is possibly important for development of metastatic cancer lesions. According to this concept, the CSC population is thought to consist of heterogeneous cells. However, whether heterogeneous CSCs exist in the primary tumor is unclear.

We identified two different populations of CSCs in the primary tumor based on E-cadherin expression status for the first time. E-cadherin-expressing CSCs ( $\mathrm{EC}^{+} \mathrm{CSCs}$ ) and E-cadherin-deficient CSCs ( $\mathrm{EC}^{-} \mathrm{CSC}$ ) existed within the EpCAM ${ }^{\text {high }} / \mathrm{CD} 44^{+}$colorectal CSC population. Expression of $C D H 1$, which encodes the E-cadherin protein, is downregulated by several EMT-related genes such as SNAIL, TWIST and $S L U G$. However, the cDNA array analysis of the present study revealed no differences in the expression of $\mathrm{CDH} 1$ or
EMT-related genes between $\mathrm{EC}^{+} \mathrm{CSC}$ and $\mathrm{EC}^{-} \mathrm{CSC}$. In addition, expression of $\mathrm{N}$-cadherin, which is believed to be highly expressed in cells during the EMT process, was not detected in $\mathrm{EC}^{-} \mathrm{CSC}$, either by flow cytometry or immunohistochemical staining. Our data revealed that the downregulation of E-cadherin expression that we observed does not represent a step in the EMT process and that distinct expression levels of E-cadherin in each CSC population may be regulated by signals other than EMT programs, such as SRC, epidermal growth factor, and WNT $(27,28)$. Thus, our data indicated that human primary CRC tissue contains CSCs that consist of $\mathrm{EC}^{+}$ CSCs and $\mathrm{EC}^{-} \mathrm{CSCs}$, and suggest that differences between these two CSC phenotypes are independent of the EMT process.

$\mathrm{EC}^{+} \mathrm{CSC}$ and $\mathrm{EC}^{-} \mathrm{CSC}$ demonstrated pathologically different phenotypes. Although both $\mathrm{EC}^{+} \mathrm{CSCs}$ and $\mathrm{EC}^{-} \mathrm{CSCs}$ had self-renewal ability and produced tumors with the same histology in immunodeficient mice, $\mathrm{EC}^{+} \mathrm{CSC}$ from primary tumors exhibited higher tumor growth potential than $\mathrm{EC}^{-}$ CSCs from primary tumors in vivo This observation strongly suggested that signal transduction-promoting cell growth was enhanced in $\mathrm{EC}^{+} \mathrm{CSC}$ s compared to $\mathrm{EC}^{-} \mathrm{CSCs}$. Such a higher growth ability of $\mathrm{EC}^{+} \mathrm{CSC}$ is possibly due to the increased expression of NANOG. NANOG is a key transcription factor that maintains the pluripotency of human embryonic stem cells by blocking differentiation and establishing the pluripotent ground state during somatic cell reprogramming (29). NANOG expression has been reported in human tumors, especially in CSCs of prostate cancer, ovarian cancer and CRC (30-32). We had previously revealed that NANOGP8 was overexpressed in the human colorectal CSC population and that downregulation of NANOG by siRNA reduced cellular proliferation (33). Therefore, the higher growth ability of 


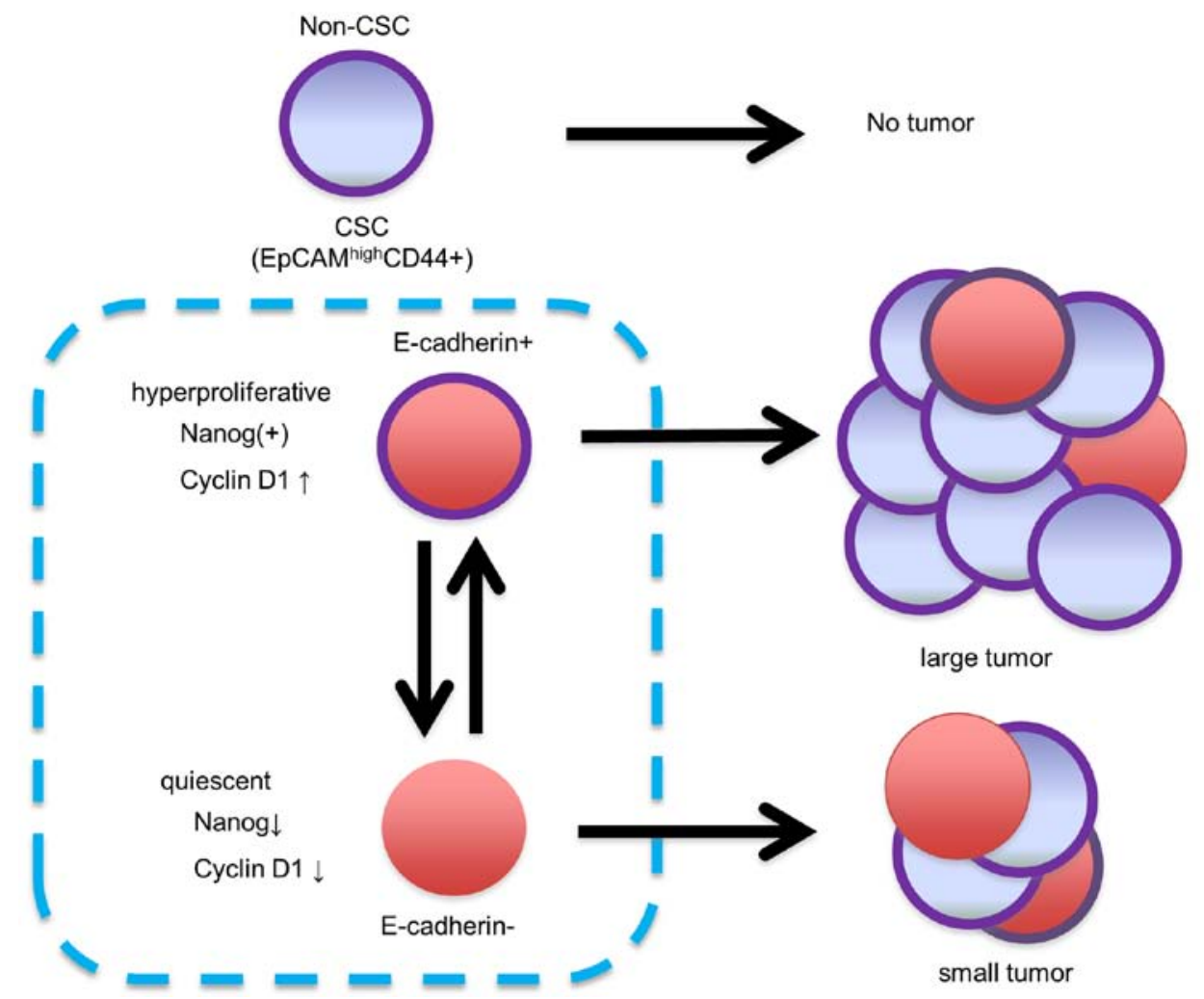

Figure 6. The concept of this study. The CSC population is a heterogeneous population that contains $\mathrm{EC}^{+}$and $\mathrm{EC}^{-}$cells. Although both $\mathrm{EC}^{+}$cells and EC cells have the ability to produce a tumor in immunodeficient mice, $\mathrm{EC}^{+}$colorectal CSCs have higher tumor growth ability. E-cadherin and NANOG may regulate colorectal CSC proliferation through the control of cyclin D1 expression.

$\mathrm{EC}^{+} \mathrm{CSC}$ could be understood in terms of their association with preferential NANOG expression. In the present study, we demonstrated that downregulation of NANOG by siRNA reduced cyclin D1 expression, and this may be the main explanation for the lower proliferation ability of EC ${ }^{-}$CSCs. In this aspect, we considered $\mathrm{EC}^{+} \mathrm{CSC}$ s to be proliferating CSCs and $\mathrm{EC}^{-} \mathrm{CSC}$ s to be quiescent CSCs.

Many transcription factors have been identified in human embryonic stem cells that are recruited to the NANOG locus to regulate its expression (29). Although direct interactions between the E-cadherin/ $\beta$-catenin signaling pathway and increased NANOG expression still remain unclear in human colorectal CSCs, Hawkins et al reported that E-cadherin promoted Nanog transcript and protein expression in mouse embryonic stem cells. In their study, they revealed that Stat3 signaling was involved in Nanog expression and that the $\beta$-catenin binding site region in E-cadherin was essential (34). The same results were reported by Valle et al (35). In addition, it was revealed that STAT3 promoted stemness in CRC $(36,37)$. With these results, STAT3 signaling may also be involved in NANOG expression by E-cadherin in human colorectal CSCs.

The present study is the first to demonstrate that the EpCAM ${ }^{\text {high }} / \mathrm{CD} 44^{+}$colorectal CSC population consists of heterogeneous populations, such as $\mathrm{EC}^{+} \mathrm{CSCs}$ and $\mathrm{EC}^{-} \mathrm{CSC}$. Although both populations possess stem cell properties, which could reconstitute tumors consisting of both populations in human CRC tissues, they exhibited pathologically different phenotypes. $\mathrm{EC}^{+} \mathrm{CSC}$ exhibited higher proliferative potential, possibly due to high NANOG expression, leading to increased cyclin D1 and cyclin B1 expression. On the other hand,
$\mathrm{EC}^{-} \mathrm{CSC}$ are thought to be in a more quiescent state than $\mathrm{EC}^{+} \mathrm{CSC}$ due to the low expression of cyclin D1. E-cadherin downregulation in $\mathrm{EC}^{-} \mathrm{CSC}$ was independent of the EMT process, and $\mathrm{EC}^{-} \mathrm{CSC}$ s have the ability to revert to $\mathrm{EC}^{+} \mathrm{CSCs}$ depending on their environment.

\section{Acknowledgements}

The authors acknowledge the assistance of Mr. Nobuhiro Torata during tissue sample collection.

\section{Funding}

The present study was supported by a grant from the Ministry of Education, Culture, Sports, Science and Technology of Japan (grant no. 15K08970).

\section{Availability of data and materials}

The datasets used during the present study are available from the corresponding author upon reasonable request.

\section{Authors' contributions}

ST, HA, TI and EB conceived and designed the study. ST, HA and TI performed the experiments and wrote the manuscript. MN performed some experiments. YK, ST, HK, KT, TU, MN, KA and EB made substantial contributions to conception and intellectual content of the studies. All authors read and approved the manuscript. 


\section{Ethics approval and consent to participate}

The study protocol was approved by the Institutional Review Board of Kyushu University Hospital in 2009 and written informed consent was obtained from patients. All animal experiments were performed in accordance with the Institutional Animal Welfare Guidelines of Kyushu University.

\section{Consent for publication}

Not applicable.

\section{Competing interests}

The authors declare that they have no competing interests.

\section{References}

1. Clevers H: The cancer stem cell: Premises, promises and challenges. Nat Med 17: 313-319, 2011

2. Dick JE: Stem cell concepts renew cancer research. Blood 112: 4793-4807, 2008.

3. Shackleton M, Quintana E, Fearon ER and Morrison SJ: Heterogeneity in cancer: Cancer stem cells versus clonal evolution. Cell 138: 822-829, 2009.

4. Takeishi S, Matsumoto A, Onoyama I, Naka K, Hirao A and Nakayama KI: Ablation of Fbxw7 eliminates leukemia-initiating cells by preventing quiescence. Cancer Cell 23: 347-361, 2013.

5. Ishimoto $T$, Nagano $O$, Yae $T$, Tamada M, Motohara $T$, Oshima H, Oshima M, Ikeda T, Asaba R, Yagi H, et al: CD44 variant regulates redox status in cancer cells by stabilizing the $\mathrm{xCT}$ subunit of system $\mathrm{xc}^{-}$and thereby promotes tumor growth. Cancer Cell 19: 387-400, 2011.

6. Diehn M, Cho RW, Lobo NA, Kalisky T, Dorie MJ, Kulp AN, Qian D, Lam JS, Ailles LE, Wong M, et al: Association of reactive oxygen species levels and radioresistance in cancer stem cells. Nature 458: 780-783, 2009.

7. Oskarsson T, Batlle E and Massagué J: Metastatic stem cells: Sources, niches, and vital pathways. Cell Stem Cell 14: 306-321, 2014.

8. Al-Hajj M, Wicha MS, Benito-Hernandez A, Morrison SJ and Clarke MF: Prospective identification of tumorigenic breast cancer cells. Proc Natl Acad Sci USA 100: 3983-3988, 2003.

9. Bonnet D and Dick JE: Human acute myeloid leukemia is organized as a hierarchy that originates from a primitive hematopoietic cell. Nat Med 3: 730-737, 1997.

10. Singh SK, Clarke ID, Terasaki M, Bonn VE, Hawkins C, Squire J and Dirks PB: Identification of a cancer stem cell in human brain tumors. Cancer Res 63: 5821-5828, 2003.

11. Takaishi S, Okumura T, Tu S, Wang SS, Shibata W, Vigneshwaran R, Gordon SA, Shimada Y and Wang TC: Identification of gastric cancer stem cells using the cell surface marker CD44. Stem Cells 27: 1006-1020, 2009.

12. Dalerba P, Dylla SJ, Park IK, Liu R, Wang X, Cho RW, Hoey T, Gurney A, Huang EH, Simeone DM, et al: Phenotypic characterization of human colorectal cancer stem cells. Proc Natl Acad Sci USA 104: 10158-10163, 2007.

13. Ricci-Vitiani L, Lombardi DG, Pilozzi E, Biffoni M, Todaro M, Peschle C and De Maria R: Identification and expansion of human colon-cancer-initiating cells. Nature 445: 111-115, 2007.

14. Huang EH, Hynes MJ, Zhang T, Ginestier C, Dontu G, Appelman H, Fields JZ, Wicha MS and Boman BM: Aldehyde dehydrogenase 1 is a marker for normal and malignant human colonic stem cells (SC) and tracks SC overpopulation during colon tumorigenesis. Cancer Res 69: 3382-3389, 2009.

15. Sada A, Jacob F, Leung E, Wang S, White BS, Shalloway D and Tumbar T: Defining the cellular lineage hierarchy in the interfollicular epidermis of adult skin. Nat Cell Biol 18: 619-631, 2016.

16. Li L, Wang S, Jezierski A, Moalim-Nour L, Mohib K, Parks RJ, Retta SF and Wang L: A unique interplay between Rap1 and E-cadherin in the endocytic pathway regulates self-renewal of human embryonic stem cells. Stem Cells 28: 247-257, 2010.

17. Miyo M, Yamamoto $\mathrm{H}$, Konno $\mathrm{M}$, Colvin $\mathrm{H}$, Nishida $\mathrm{N}$, Koseki J, Kawamoto K, Ogawa H, Hamabe A, Uemura M, et al: Tumour-suppressive function of SIRT4 in human colorectal cancer. Br J Cancer 113: 492-499, 2015.
18. Bolstad BM, Irizarry RA, Astrand M and Speed TP: A comparison of normalization methods for high density oligonucleotide array data based on variance and bias. Bioinformatics 19: 185-193, 2003.

19. Gentleman RC, Carey VJ, Bates DM, Bolstad B, Dettling M, Dudoit S, Ellis B, Gautier L, Ge Y, Gentry J, et al: Bioconductor: Open software development for computational biology and bioinformatics. Genome Biol 5: R80, 2004.

20. Quackenbush J: Microarray data normalization and transformation. Nat Genet 32 (Suppl): S496-S501, 2002.

21. Soncin F and Ward CM: The function of e-cadherin in stem cell pluripotency and self-renewal. Genes (Basel) 2: 229-259, 2011.

22. Hosokawa K, Arai F, Yoshihara H, Iwasaki H, Nakamura Y, Gomei Y and Suda T: Knockdown of N-cadherin suppresses the long-term engraftment of hematopoietic stem cells. Blood 116: 554-563, 2010

23. Mani SA, Guo W, Liao MJ, Eaton EN, Ayyanan A, Zhou AY, Brooks M, Reinhard F, Zhang CC, Shipitsin M, et al: The epithelial-mesenchymal transition generates cells with properties of stem cells. Cell 133: 704-715, 2008

24. Fischedick G, Wu G, Adachi K, Araúzo-Bravo MJ, Greber B, Radstaak M, Köhler G, Tapia N, Iacone R, Anastassiadis K, et al: Nanog induces hyperplasia without initiating tumors. Stem Cell Res 13: 300-315, 2014.

25. Han J, Zhang F, Yu M, Zhao P, Ji W, Zhang H, Wu B, Wang Y and Niu R: RNA interference-mediated silencing of NANOG reduces cell proliferation and induces G0/G1 cell cycle arrest in breast cancer cells. Cancer Lett 321: 80-88, 2012.

26. Son MY, Choi H, Han YM and Cho YS: Unveiling the critical role of REX1 in the regulation of human stem cell pluripotency. Stem Cells 31: 2374-2387, 2013.

27. Behrens J, Vakaet L, Friis R, Winterhager E, Van Roy F, Mareel MM and Birchmeier W: Loss of epithelial differentiation and gain of invasiveness correlates with tyrosine phosphorylation of the E-cadherin/beta-catenin complex in cells transformed with a temperature-sensitive v-SRC gene. J Cell Biol 120: 757-766, 1993.

28. Nelson WJ and Nusse R: Convergence of Wnt, beta-catenin, and cadherin pathways. Science 303: 1483-1487, 2004.

29. Saunders A, Faiola F and Wang J: Concise review: Pursuing self-renewal and pluripotency with the stem cell factor Nanog. Stem Cells 31: 1227-1236, 2013.

30. Gu G, Yuan J, Wills M and Kasper S: Prostate cancer cells with stem cell characteristics reconstitute the original human tumor in vivo. Cancer Res 67: 4807-4815, 2007.

31. Chiou SH, Yu CC, Huang CY, Lin SC, Liu CJ, Tsai TH, Chou SH, Chien CS, Ku HH and Lo JF: Positive correlations of Oct-4 and Nanog in oral cancer stem-like cells and high-grade oral squamous cell carcinoma. Clin Cancer Res 14: 4085-4095, 2008.

32. Ibrahim EE, Babaei-Jadidi R, Saadeddin A, Spencer-Dene B, Hossaini S, Abuzinadah M, Li N, Fadhil W, Ilyas M, Bonnet D and Nateri AS: Embryonic NANOG activity defines colorectal cancer stem cells and modulates through AP1- and TCF-dependent mechanisms. Stem Cells 30: 2076-2087, 2012.

33. Uchino K, Hirano G, Hirahashi M, Isobe T, Shirakawa T, Kusaba H, Baba E, Tsuneyoshi M and Akashi K: Human Nanog pseudogene 8 promotes the proliferation of gastrointestinal cancer cells. Exp Cell Res 318: 1799-1807, 2012.

34. Hawkins K, Mohamet L, Ritson S, Merry CL and Ward CM: E-cadherin and, in its absence, $\mathrm{N}$-cadherin promotes Nanog expression in mouse embryonic stem cells via STAT3 phosphorylation. Stem Cells 30: 1842-1851, 2012.

35. del Valle I, Rudloff S, Carles A, Li Y, Liszewska E, Vogt R and Kemler R: E-cadherin is required for the proper activation of the Lifr/Gp130 signaling pathway in mouse embryonic stem cells. Development 140: 1684-1692, 2013.

36. Lin L, Liu A, Peng Z, Lin HJ, Li PK, Li C and Lin J: STAT3 is necessary for proliferation and survival in colon cancer-initiating cells. Cancer Res 71: 7226-7237, 2011.

37. Kim BR, Oh SC, Lee DH, Kim JL, Lee SY, Kang MH, Lee SI, Kang S, Joung SY and Min BW: BMP-2 induces motility and invasiveness by promoting colon cancer stemness through STAT3 activation. Tumour Biol 36: 9475-9486, 2015. International (CC BY-NC-ND 4.0) License. 